\title{
Amalgamating Spirituality with Education for Harmonious Exchange and Deepened Wisdom
}

\author{
Pallavi Pathak \\ ${ }^{\text {a }}$ School of Management Sciences, Varanasi, India \\ 1 pallavipathak@smsvaranasi.com
}

\section{ARTICLE INFO}

Article history

Received 10 September 2019

Revised 20 October 2020

Accepted 30 October 2020

Keywords

Education

Spirituality

Balance

Wisdom

\section{ABSTRACT}

This article examines the balance between education and spirituality for harmonious exchange and deepened wisdom. Literature studies with the spiritual approach are used in this study. By reconnecting spirituality and education, we can develop an integrated education system that allows students to connect mentally between the intellectual, emotional and spiritual dimensions. Truth, meaning, and the real power of life are within us, and we must release the soul to unleash the real potential. When spirituality is fully embraced in the education system, it will foster a dynamic balance within the students themselves.

This is an open access article under CC-BY-SA License

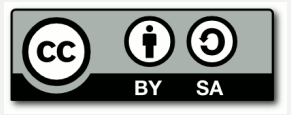

\section{Introduction}

"By spiritual training, I mean education of the heart" - Mahatma Gandhi

Spirituality has several undertones and influences both hermit and socializer alike. Rightly said Spirituality commences where science terminates. Spirituality demonstrates what scientists have no ways of measuring or explaining. When science cannot explain a phenomenon, they often label it as an anomaly. Others call it a miracle.

Our knowledge limits us, whereas the universe has no limitations. Spiritual understanding has no bounds. Just as in the spiritual world, every possible combination exists in this universe. The universe is too large to be confined to the smallness of human discoveries, or to be comprehended by the human mind.

There should be a deeper connection with one's mind and spirit leading to a spiritual harmony between thoughts, emotions, and actions. Having the ability to extend this harmony to the community seems to be the only rational way to handle the arduous task of addressing mammoth problems of social injustice, ecological devastation, extreme economic disparities, destructive conflicts, and terrorism plaguing the planet at the moment. This spiritual harmony is also a potential source of happiness and peace.

To achieve real success, we must find unity and alignment between Spirituality and Materialism. It is vital to have the right mix of spiritualism and materialism. This article explores how spirituality can enrich students' ability and wisdom through several ways of learning, especially in India, the country that is rich with ancient spirituality. 


\section{Method}

This paper is a literature study by means of reflective account. Ancient script comprising The Vedas, Upanishads, and Puranas as well as spiritual literature studies such as Krishnamurti, Emmons are explored. Shanti Mantra that has deep spiritual impacts to students are also discussed. The article further explains how spiritual intelligence can be advanced by integrating spirituality to education curriculum.

\section{Results and Discussion}

Relating spirituality with education is not a new perspective in India, where spirituality is the essence of learning since ancient times. The Vedas, Upanishads, and Puranas mention spirituality and education since ancient times.The most ancient Sanskrit text Rigveda says, "Let noble thoughts come to me from all directions." This Vedic mantra itself represents the core of spirituality that wisdom does not confine to the boundaries of any conventional religion, rituals, region, state, customs, and ceremonies, but goes much beyond that.

In the article 'What does Spirituality in Education Mean?' Laura Jones rightly stated that:

"Spirituality in education refers to no more-and no less-than a deep connection between student, teacher, and subject-a connection so honest, vital, and vibrant that it cannot help but be intensely relevant. Nourishment of this spark in the classroom allows it to flourish in the world, in the arenas of politics, medicine, and engineering - wherever our students go after graduation." [1]

A mind that is trained to fit in a particular framework and stuffed with factual knowledge may acquire degrees, prizes, and medals, but fail to meet life with all its subtleties, complexities, varieties, challenges and its profundities. J. Krishnamurti, a renowned philosopher and prolific speaker on spirituality and education, asserted:

"The vital thing is to educate the educator, and that is one of the most difficult undertakings. The system of thought or a pattern of action already crystallizes the educator... One cannot bring up a child to be an integrated individual if one does not understand integration in oneself." [2]

For him, the thing that is of primary importance is the intelligence of the educator himself. Katha Upanishad also emphasizes the continuous harmonious learning process between the student and the teacher in its 'Shanti Mantra' (see Appendix 1). This mantra highlights the coordinated exchange of mental, spiritual, emotional, and intellectual energies between the teacher and the student. This healthy mutual relationship enables one to produce ideal results and learning for both student and teacher, which is the real purpose of education[3].

There is a dire need to turn the teachings towards dimensions of values, cultural, ethical, divine, and spiritual potentialities. In the present scenario, with the growing technological advancement use of social media, materialism, depression, conflicts, it is becoming inevitable to look into the things with a holistic approach and to take the vital energy from our roots. By reconnecting spirituality and education, we can develop an integrated education system the enables the students to maintain mental equilibrium between the intellectual, emotional, and spiritual dimensions. The real truth, meaning, and strength of life lie within us, and one has to delve into the soul to bring out real potential. This can never be done successfully with a greedy mind addicted to desires, greed, lust, jealousy, and comforts.

\section{Spiritual Intelligence}

Spiritual intelligence is the ability to draw on one's spiritual abilities and resources in order to better identify, find meaning in, and resolve existential, spiritual, and practical issues [4]. Such resources and abilities can be prayer, intuition, or even transcendence, need to be relevant in facilitating an individual's capabilty for finding meaning in experiences, for facilitating problemsolving, and for enhancing an individual's capacity for adaptive decision making." Spiritual 
intelligence is "the adaptive use of spiritual information to facilitate everyday problem solving and goal attainment." There are five components of spiritual intelligence, (1) ability to utilize spiritual inputs to solve problems, (2) ability to enter heightened states of consciousness, (3) ability to invest everyday experiences, (4) capacity for transcendence of physical and material, and (5) capacity to exhibit virtuous behavior (to show forgiveness, to express gratitude, to be humble to display compassion [5].

Education and curriculum should be designed to cultivate the necessary foundation of spirituality. Satisfactory answers to the tough question of life are the end goal of education. The essence of life lies in the happiness that one feels from within and is not dependent on any material possessions in the outer world. When spirituality is embraced entirely to our education system, it would surely enable the posterity to develop an art of dynamic equilibrium. They never tend to extremes and mend their ways in which they connect to others, to themselves, and nature, enabling them to step ahead in life in a more beautiful world. To build a better world for future generations, One should he endeavor towards holistic education based on spirituality. We should educate students in a way that enables them to explore deeper and higher dimensions of human resources so that they may understand the subtleties of life and answer the complex questions related to the very human existence [6-8]

Our ancestors must surely have this in mind when they wrote in Isavasya Upanishad: "The truth is covered with a golden layer, and truth can only be realized after this golden layer of illusion is removed". All our ancient text Upanishads end with Om Shanti Shanti Shanti. The threefold Shanti means freedom from tritap (ordeals): Adidaivik, Adibhautik, Aadhyatmik. We pray for the peace at three levels, i.e., the order in the entirety of one's being. That is the real end goal of education.

\section{Conclusion}

Thus to achieve real success, we must find unity and alignment between Spirituality and Materialism. It is vital to have the right balance of spiritualism and materialism. This combination is not merely confined to gaining knowledge, collection of information, or facilitating our enhancement of skill learning.

Equally, the crucial issue is to prepare the future generation to promisingly and confidently respond to the mounting challenges of the present-day life and make the younger generation feel more favorable for their growth potential. The deepening roots of materialistic society foster negative feeling like jealousy, greed, lust, luxury, desires, fear, the helplessness that utterly ignores the importance of spiritual values and creates innumerable problems that the society is facing today at one level or the other.

\section{References}

[1] Laura J. What Does Spirituality in Education Mean? J Coll Character 2005;6:1-7.

[2] Krishnamurti J. Fifth Talk in Poona: Verbatim Report. 1946.

[3] Shankar SSR. Management Mantras. Jaico Books; 2013.

[4] Srivastava PS. Spiritual Intelligence: An Overview. Int J Multidiscip Res Dev 2016;3:2247.

[5] Emmons R. Is Spirituality an Intelligence? Motivation, Cognition, and the Psychology of Ultimate Concern. Int J Psychol Relig 2000;10:3-26.

[6] Chaturvedi B. Kautilya's Arthashastra. Diamond Pocket Books; 1999.

[7] Chakroborty A. Karma - The spiritual style of Management (for Today's Manager). New Delhi: Crest Publishing House.; 2001.

[8] Moore M. How to Master Change in your life. New Delhi: New Age Books.; 2001. 
Appendix 1. Shanti Mantra (from https://inspirationyoga.eu/resources/shanti-mantra/)

\title{
Vedic Peace Chants
}

(Translation by Sri Swami Shivananda of The Divine Life Society, Rishikesh)

\author{
Om sarveshaam swastir bhavatu \\ Sarveshaam shantir bhavatu \\ Sarveshaam poornam bhavatu \\ Sarveshaam mangalam bhavatu \\ Sarve bhavantu sukhinah \\ Sarve santu niraamayaah \\ Sarve bhadraani pashyantu \\ Maakaschit duhkha bhaag bhavet \\ Om shantih shantih shantih!
}

Meaning:

Auspiciousness (swasti) be unto all; peace (shanti) be unto all; fullness (poornam) be unto all; prosperity (mangalam) be unto all.

May all be happy! (sukhinah)

May all be free from disabilities! (niraamayaah)

May all look (pashyantu)to the good of others!

May none suffer from sorrow! (duhkha)

Om peace, peace, peace!

\section{Om asato maa satgamaya \\ Tamaso maa jyotir gamaya \\ Mrityor maa amritam gamaya \\ Om shantih shantih shantih!}

Meaning:

Lead us from the unreal to the real (from untruth to truth)

From darkness to light

From death to immortality

Om peace, peace, peace!

\section{Om poornamadah poornamidam \\ Poornaat poornamudachyate \\ Poornasya poornamaadaya \\ Poornamevaavashishyate \\ Om shantih shantih shantih!}

Meaning:

That (pure consciousness) is full (perfect);

this (the manifest universe of matter;

of names and forms being maya) is full.

This fullness has been projected from that fullness.

When this fullness merges in that fullness, all that remains is fullness.

Om peace, peace, peace! 
Om sham no mitrah sham varunah sham no bhavatvaryamaa Sham na indro brihaspatih sham no vishnururukramah

Namo brahmane namaste vaayo twameva pratyaksham

Brahmaasi twaameva pratyaksham brahma vadishyami

Tanmaamavatu tadvaktaaramavatu Avatu maam avatu vaktaaram. Om shantih shantih shantih!

Meaning:

May Mitra, Varuna and Aryama be good to us!

May Indra and Brihaspati and Vishnu of great strides be good to us!

Prostrations unto Brahman! (Supreme Reality).

Prostrations to Thee, O Vayu! Thou art the visible Brahman.

I shall proclaim Thee as the visible Brahman.

I shall call Thee the just and the True.

May He protect the teacher and me! May he protect the teacher!

Om peace, peace, peace!

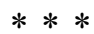

Om saha naavavatu sahanau bhunaktu

Saha veeryam karavaavahai

Tejasvi naavadheetamastu maa vidvishaavahai

Om shantih shantih shantihi

Meaning:

May He protect us both (teacher and the taught)!

May He cause us both to enjoy the bliss of Mukti (liberation)!

May we both exert to discover the true meaning of the sacred scriptures!

May our studies be fruitful!

May we never quarrel with each other!

Let there be threefold peace.

$$
* * *
$$

Namaste sate te jagat kaaranaaya

Namaste chite sarva lokaashrayaaya

Namo dvaita tattwaya mukti pradaaya

Namo brahmane vyaapine shaashvataaya

Om shantih shantih shantih!

\section{Meaning:}

Salutations to that Being, the cause of the universe!

Salutations to that Consciousness, the support of all the worlds!

Salutations to that One Truth without a second, which gives liberation!

Salutations to that pure, eternal Brahman who pervades all regions!

Om peace, peace, peace!

$$
* * *
$$




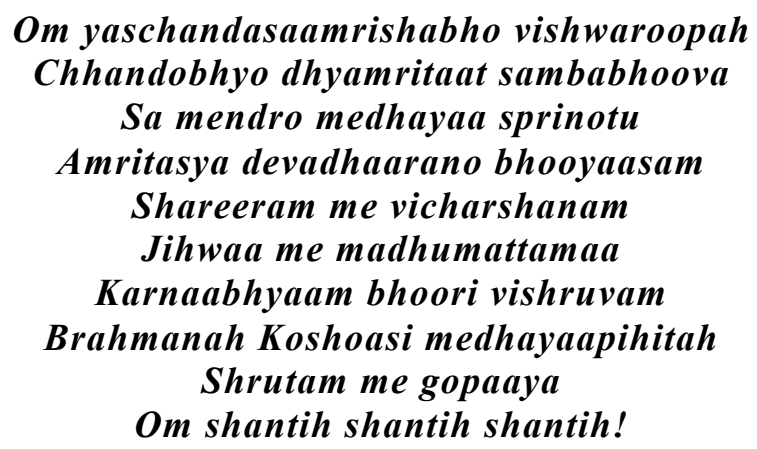

\section{Meaning:}

May He, the Lord of all, pre-eminent among the Vedas and superior to the nectar contained in them, bless me with wisdom! May I be adorned with the knowledge of Brahman that leads to immortality!

May my body become strong and vigorous (to practise meditation)!

May my tongue always utter delightful words!

May I hear much with my ears!

Thou art the scabbard of Brahman hidden by worldly taints (not revealed by impure, puny intellects).

May I never forget all that I have learnt!

Om peace, peace, peace!

Om aham vrikshasya rerivaa

Keertih prishtham gireriva

Urdhwapavitro vaajineeva swamritamasmi

Dravinam savarchasam

Sumedhaa amritokshitah

Iti trishankor vedaanu vachanam

Om shantih, shantih, shantih!

Meaning:

I am the destroyer of the tree (of samsar; worldly life).

My reputation is as high as the top of the hill.

I am in essence as pure as the sun.

I am the highest treasure.

I am all-wise, immortal and indestructible.

This is Trishanku's realisation.

Om peace, peace, peace!

Om aapyaayantu mamaangaani vaak

Praanashchakshuh shrotramatho

Balamindriyaani cha sarvaani sarvam brahmopanishadam

Maaham brahma niraakuryaam maa maa brahma niraakarod

Niraakaranamastva niraakaranam me astu

Tadaatmani nirate ya upanishatsu dharmaaste

Mayi santu te mayi santu.

Om shantih, shantih, shantih! 


\section{Meaning:}

May my limbs, speech, Prana, eye, ear and power of all my senses grow vigorous! All is the pure Brahman of the Upanishads.

May I never deny that Brahman!

May that Brahman never desert me!

Let that relationship endure.

Let the virtues recited in the Upanishads be rooted in me.

May they repose in me!

Om peace. peace. peace!

Om vaang me manasi pratishthitaa

Mano me vaachi pratishthitam

Aaveeraaveerma edhi vedasya ma aanisthah

Shrutam me maa prahaaseer anenaadheetena

Ahoraatraan samdadhaami ritam vadishyaami

Satyam vadishyaami tanmaamavatu tadvaktaaramavatu

Avatu maam avatu vaktaaram avatu vaktaaram

Om shantih, shantih, shantih!

Meaning:

Let my speech be rooted in my mind.

Let my mind be rooted in my speech.

Let Brahman (Supreme Reality) reveal Himself to me.

Let my mind and speech enable me to grasp the truths of the Vedas.

Let not what I have heard forsake me.

Let me spend both day and night continuously in study.

I think truth, I speak the truth.

May that Truth protect me! May that Truth protect the teacher!

Let peace prevail against heavenly, worldly and demoniacal troubles.

Om peace, peace, peace!

Om bhadram no apivaataya manah.

Om shantih, shantih, shantih!

Meaning:

Salutations! May my mind and all these

(the body, senses, breath etc.) be good and well!

Om peace, peace. peace! 
Om bhadram karnebhih shrunuyaama devaah

Bhadram pashyemaakshabhiryajatraah

Sthirairangaistushtuvaamsastanoobhih

Vyashema devahitam yadaayuh

Swasti na indro vridhashravaah

Swasti nah pooshaa vishwavedaah

Swasti nastaarkshyo arishtanemih

Swasti no brihaspatir dadhaatu.

Om shantih, shantih, shantih!

Meaning:

Om, O worshipful ones,

may our ears hear what is good and auspicious!

May we see what is auspicious!

May we sing your praise, live our allotted span of life

in perfect health and strength!

May Indra (who is) extolled in the scriptures,

Pushan, the all-knowing Trakshya, who saves from all harm, and Brihaspati who protects our spiritual lustre, vouchsafe prosperity in our study of the scriptures and the practice of the truths contained therein!

Om peace, peace, peace!

\section{Om yo brahmaanam vidadhaati poorvam \\ Yo vai vedaanshcha prahinoti tasmai \\ Tam ha devmaatma buddhi prakaasham \\ Mumukshurvai sharanamaham prapadye $<$ \\ Om shantih, shantih, shantih!}

Meaning:

He who creates this entire universe in the beginning, and He about whom the Vedas gloriously praise and sing, in Him I take refuge with the firm faith and belief that my intellect may shine with Self-knowledge.

Om peace, peace, peace!

\section{Om vishwaani deva savitar duritaani paraasuva \\ Yad bhadram tanma aasuva \\ Om shantih shantih shantih!}

\section{Meaning:}

O all pervading, Supreme Lord, the effulgent Creator, we place our faith and trust entirely in Thee.

Keep away from us all that is evil and bestow upon us all that is good.

Om peace, peace, peace! 


\section{Om agne naya supathaa raaye asmaan \\ Vishwani deva vayunaani vidvaan; \\ Yuyodhyas majjuhu raanmeno \\ Bhooyishthaam te nama-uktim vidhema. \\ Om shantih shantih shantih!}

\section{Meaning:}

O Supreme Lord, who art light and wisdom,

Thou knowest all our thoughts and deeds.

Lead us by the right path to the fulfilment of life, and keep us away from all sin and evil.

We offer unto Thee, O Lord, our praise and salutation.

Om peace, peace, peace!

$$
* * *
$$

\section{Tvamekam sharanyam tvamekam varenyam \\ Tvamekam jagatpaalakam svaprakaasham; \\ Tvamekam jagatkartu paatruprahartru \\ Tvamekam param nishchalam nirvikalpam. \\ Om shantih shantih shantih!}

\section{Meaning:}

O Thou my only refuge,

O Thou my one desire,

$\mathrm{O}$ Thou the one protector of the world, the radiant One.

$\mathrm{O}$ Thou the creator, sustainer and dissolver of the whole world,

$\mathrm{O}$ Thou the one great motionless Being, free from change and modification.

Om peace, peace, peace!

Vayam tvaam smaraamo vayam tvaam bhajaamo

Vayam tvaam jagat saakshiroopam namaamah;

Sadekam nidhaanam niraalambameesham

Bhavaambhodhi potam sharanyam vrajaamah.

Om shantih shantih shantih!

\section{Meaning:}

O Thou eternal all-pervading witness of the whole universe, we meditate on the one Truth.

We silently adore Thee and offer Thee our salutation. We take complete refuge in that one Almighty Being, the basis of everything, self-supporting and supreme,

a vessel in the stormy sea of life.

Om peace, peace, peace! 


\section{Om dyauh shaantih Antariksham shaantih \\ Prithivee shaantih Aapah shaantih \\ Oshadhayah shaantih Vanaspatayah shaantih \\ Vishvedevaah shaantih Brahma shaantih \\ Sarvam shaantih Shaantireva shaantih \\ Saamaa shaantiredhih \\ Om shantih, shantih, shantih!}

Two interpretations:

\section{Meaning according to Swami Shivananda} Divine Life Society, Rishikesh, India

O Supreme Lord, Thy celestial regions are full of peace and harmony; peace reigns on Thy earth and Thy waters.

Thy herbs and trees are full of peace.

All Thy forces of nature are full of peace and harmony.

There is peace and perfection in Thy eternal knowledge;

everything in the universe is peaceful, and peace pervades everywhere.

O Lord, may that peace come to me!

\section{Meaning according to Swami Abhedananda}

Ramakrishna Vedanta Math, India

May peace radiate there in the whole sky as well as in the vast ethereal space everywhere.

May peace reign all over this earth,

in water and in all herbs, trees and creepers.

May peace flow over the whole universe.

May peace be in the Supreme Being Brahman.

And may there always exist in all peace and peace alone.

Om peace, peace and peace to us and all beings! 